\title{
Analysis of the Influence of Lifestyle on Purchasing Decision for Samsung Smartphone Products in Jakarta
}

\author{
Ryan Tantri Andi and Mochammad Mukti Ali
}

\begin{abstract}
This study is part of a thesis that discussed the factors that affect purchasing decision for Samsung smartphone products in Jakarta and the purpose of this study was to analyze in detail the influence of lifestyle on purchasing decision for Samsung brand smartphone products in Jakarta. This study used primary data in the form of the manual questionnaire and distributed randomly in various regions in Jakarta. The method used was judgment sampling which means the respondent was given questions that had been determined by the researchers. The population studied was Samsung Galaxy Note smartphone users in Jakarta. The sample was taken using the Lemeshow formula because the number of Samsung Galaxy Note users was unknown and the results obtained using the Lemeshow formula were 384 people. The results of the study showed that lifestyle had a positive and significant effect on purchasing decision.
\end{abstract}

Index Terms-lifestyle, consumer behavior, dimensions of lifestyle, dimension of consumer behavior

\section{INTRODUCTION}

The rapid progress of technology in the digital era has changed human habits in living life. Almost all aspects of human activity involve technology. One kind of technology that affects human life is communication technology.

The development of smartphone users in Indonesia has increased from year to year. According to statistical data from the company Katadata that is engaged in media, data, and online research in 2018, the number of smartphone users in Indonesia from 2016 - 2019 was recorded at 65.2 million people in 2016 and then increased in 2017 by 74.9 million people or $13.8 \%$, then in 2018 smartphone users became 83.5 million or having an increase of $10.9 \%$ [1].

A new phenomenon that causes the development of smartphone technology to be faster and more sophisticated is Android. Android actually did not just become big in a short time, Android is an operating system that translates Google's vision and ambitions. Besides can be used for free, Android also offers a variety of many applications that can be downloaded for free. This is what increasingly makes consumers interested in smartphones with Android systems. [2] One smartphone manufacturer using Android system that controls the Indonesian market is Samsung. Under the name of Samsung Electronics, which was founded in 1969 in Daegu, South Korea. The smartphones sold by Samsung have several smartphone classes lines which are divided

Published on August 5, 2019.

Ryan Tantri Andi, Mercubuana University, Fakultas pascasarjana magister manajemen, Jakarta Barat, 11650 Indonesia (e-mail: r.tantri.a@) gmail.com).

Mochammad Mukti Ali, Mercubuana University, Fakultas pascasarjana magister manajemen, Jakarta Barat, 11650 Indonesia (e-mail: mukti_gte@ yahoo.com). into low-end class consisting of entry class and Galaxy J then the middle-end class which has better features than low-end class and the last is high-end class which is a flagship product cluster from Samsung consisting of Galaxy $\mathrm{S}$ and Galaxy Note [3].

This study discussed the Samsung Galaxy Note with the support of the finding that Samsung Galaxy Note smartphone sales data was lower than Samsung Galaxy S even though the Samsung Galaxy Note smartphone features were superior to Samsung Galaxy S.

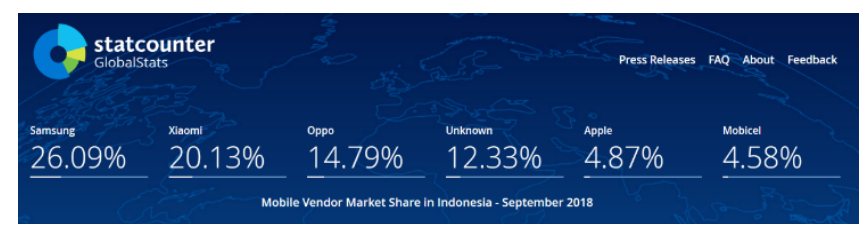

Figure 1. Marketshare Smartphone Manufacturers in Indonesia September 2018

Based on Figure 1, Samsung controlled the marketshare in Indonesia by $26.09 \%$ compared to other smartphone manufacturers such as Xiaomi, which was in the second rank of the marketshare and were followed by Oppo, Apple, and other manufacturers [4].

Based on the markethare data and the Samsung smartphone series clusters which were superior to other smartphone manufacturers, Samsung was able to meet the expectations of the smartphone market in Indonesia so that it became the market leader. This was supported by the variety of smartphone products sold by Samsung at varying prices so that lower-class to upper-class consumers can buy Samsung smartphones. When buying and consuming a product, consumers will certainly first consider what products they need, when, how and where to buy and what they will do with the product. Consumers will make a decision to buy the product if the product can meet their needs, has benefits that can be felt, or just be able to support their lifestyle [5].

Lifestyle involves something that is more than just a social class or a person's personality. Lifestyle as the widest aspect of the macro-social environment and contained in personal factors of consumer behavior certainly has a strong effect on consumer purchasing behavior, and ultimately determines one's purchasing decision for the product to be bought [6]. In addition, the study conducted by [7] with the title "The effect of lifestyle on the purchase decision process in purchasing Android-based smartphone" also explained that part of the lifestyle, which is interest factors, have a significant effect on purchasing decisions [7].

The purchasing decision is always interesting to study because many factors can influence consumers in acting or doing something about a product or service. Smartphone products that are increasingly in demand in Indonesia cause 
the public in need of making a consideration regarding purchasing decision. As mentioned earlier there are several factors such as lifestyle, product quality, and price as the indicators in making a purchasing decision [7].

The researchers also conducted a survey to 25 people to add to the research data related to factors that affect purchasing decision for people who use Samsung Note smartphone products in Jakarta. Determination of the factors used in the pre-survey was adopted from several studies which also had similar titles starting from the study by [5] with the title "Purchasing decision for smartphone made by University students: reference group or lifestyle" which contained a statement from Kotler \& Keller (2009) stated that consumer purchasing decision is also affected by several factors, both individual and environmental.

Some environmental factors that affect purchasing decision such as cultural factors, social factors, personal factors, and psychological factors, on the social side, there are families, reference groups, roles, and status, while on the personal side, there are lifestyle, age, work, and personality. At the time of making a purchasing decision, doubts sometimes arise in the minds of consumers, which makes the purchasing decision process takes longer. Besides that, lifestyle is also often used as motivation and guidance in the process of making a purchase decision for a product [5].

Other factors that affect consumers to make purchases will continue to be increased, such as features, prices, brand image, promotion, product quality, and others. Samsung continues to improve quality, carry out product innovations, and continues to carry out its product mix [8].

Based on the pre-survey results, lifestyle obtained significant results and affected the purchasing decision. On the basis of background, previous research, and the results of pre-surveys that had been conducted, the writers conducted this study entitled "The effect of product quality, price, and lifestyle on the purchasing decision for Samsung smartphones in Jakarta". In this study, limitation of the problem had been made with the aim that this study is directed, focused and does not deviate from the subject of study, they are:

- Research products were only for Samsung smartphones, not including all products manufactured by Samsung such as Power Bank, TV, Refrigerator, Washing Machine and others.

- Data on smartphone users in Indonesia in 2016 2019 was taken from one of the online media, data and research websites in Indonesia.

- This study only focused on the effect of lifestyle on the purchasing decision for Samsung Galaxy Note smartphone product

In accordance with the background of the research above, the researchers formulated a research problem to be discussed, does lifestyle have a positive and significant effect on the purchasing decision for Samsung Galaxy Note smartphone product in Jakarta?

With the formulation of the problem, it can be seen that the purpose of this study was to analyze the effect of lifestyle on the purchasing for Samsung note smartphone in Jakarta.

\section{THEORETICAL BACKGROUND AND HYPOTESIS}

\section{A. Lifestyle and its dimensions}

Lifestyle develops because there are needs, demands, and reinforcements where if the behavior is repeated after it brings satisfaction or enjoyment then there is no punishment attached to it.

Consumers are more selective and more careful when faced with a buying process. This consumer behavior involves a variety of activities that are mentally, emotionally and physically [9].

\section{a. Lifestyle}

According to Kotler et al (2009), "lifestyle is a pattern of one's life as expressed in activities, interests, and opinions". lifestyle is capturing the whole pattern of someone acting or networking in the world more than a person's personal profile or social class. The concept of lifestyle and social which is affected by external and internal influences results in a decision-making process for products based on needs and desires [10].

\section{b. Dimensions of Lifestyle}

According to Solomon (2009) in the study [11], lifestyle is a life pattern that describes activities, interests, and opinions of individuals who interact with the environment and it is a quantitative measurement that can be used to analyze very large data [11].

Mowen (2003) in the study [6] explained that psychography is often interpreted as a measurement of AIO (activity, interest, opinion) presented as follows:

- Activity asks consumers to identify what they are doing.

- Interest is a personal factor of consumers in influencing the decision-making process. Every company is required to understand the interests and desires of its customers.

- Opinion investigates views and feelings about topics of world events, trends that are currently in. Opinion is the opinion of every consumer that comes from their own mouth.

\section{B. Purchasing Decision and its Dimensions}

The definition of purchasing decision according to Assauri (2010: 139) in research [14] is a process of making a purchasing decision that includes determining whether to carry out with the purchasing or not, and this decision is obtained from previous activities [14].

\section{a. Purchasing Decision}

According to Kotler and Armstrong (2010) in the study [13] there are five stages of the purchasing decision process, recognition, evaluation, searching alternative information, purchasing decision, and post-purchase behavior. Consumers often have unlimited desires that demanded to be fulfilled and they will get satisfaction after getting something newer or better. This can be attributed to the fact that each individual has his/her own behaviors, attitudes, and thoughts when choosing products and making a purchasing decision [13]. 


\section{b. Dimensions of Purchasing Decision}

According to Kotler (2012), the purchasing decision taken by the consumers is actually a collection of a number of decisions. Every purchasing decision has a structure of seven components. These components are discussed below in relation to the purchase of a product, they are:

1. The decision about product selection, consumers can make a decision to buy a handphone. In this case, the company must focus its attention on people who are interested in buying mobile phones as well as other alternatives they consider.

2. The decision about the type of product, consumers can make a decision to buy a particular product. The decision concerns the pattern of size, sound quality, style and so on. In this case the company must conduct marketing research to find out the preferences of consumers about the products they want in order to optimize the attractiveness of their brands

3. The decision about brand selection, consumers must make a decision about which brands can be purchased. Each brand has its own differences. In this case, the company must know how consumers choose a brand

4. The decision about the selection of outlets/counters, consumers must make a decision where the handphone can be purchased. In this case, producers, wholesalers, and retailers must know how consumers choose a particular seller

5. The decision about the number of products, consumers can make a decision about how many products they can buy at a time. In this case, the company must prepare the fitting number of products according to the different desires of the buyers.

6. The decision about the time of purchase, consumers can make a decision about when to make a purchase. This problem can involve the availability of money to buy a handphone. Therefore, companies must know the factors that affect consumer decision in determining the time of purchase. Thus, the company can manage the production time and marketing activities

7. Payment methods, consumers must make a decision about the payment method of products purchased, whether in cash or in installments [15].

Based on the theory above, the selected dimensions of purchasing decision used in this study that were relevant: The decision about product selection, The decision about brand selection, The decision about the selection of outlets/counters, The decision about the time of purchase, payment methods. The reasons for several dimensions were not included in the study such as the decision about the type of product and the decision about the number of products, because the type of product in this study was a type of smartphone, not other types of products. While the number of products was not limited in this study, with the note that consumers had one or more Samsung smartphone products.

\section{Relationship of Lifestyle Dimensions to Purchasing Decision Dimensions}

According to research by Prasetyo (2009) in the journal of [6] states that lifestyle variables have a positive relationship and have a strong enough influence on the purchase decision variable. Another statement about lifestyle stated by Mandey (2009) in his research said that lifestyle is part of consumer behavior that can influence consumer actions to make purchases. Consumer purchasing decisions can not be separated from the lifestyle of those who want to buy products that are useful and have good quality. Diversity of consumers in meeting their needs is influenced by lifestyle characteristics that are measured based on the activities in which a person performs activities in meeting his needs such as work, hobbies, shopping, entertainment, sports, and one's interests based on the desires of the desired product, as well as one's opinion or view of the product which will be purchased so that it can influence consumer decision behavior [9]. The research of Long-Yi Lin and Hsing-Yu Shih (2012) also explains that lifestyle has an important role in consumer purchasing decisions. Consumers are motivated to buy products in order to maintain or pursue certain lifestyles. According to Berkman and Gilson in Aresa (2012) research using the concept of AIO (Activity, Interest, Opinion) can explain differences in purchases made by consumers for a product based on lifestyle and their activities, what they consider important about their surrounding environment and demographic profile [6].

\section{Hypothesis}

Based on the study of the theory that has been explained above, the researchers determined the hypothesis that lifestyle has a positive and significant effect on purchasing decision.

\section{METHODOLOGY}

\section{A. Type of Research}

The type of research was the explanatory research which is a study with object reviewed examined based on the relationships between hypothesized variables. There was a hypothesis that had been determined by the researchers to be tested the truth [7].

While the approach that carried out in this study was a quantitative causal hypothesis testing approach wherein the hypothesis would be tested regarding the relationship between variables so that conclusions could be drawn to explain phenomena based on existing theories [11].

To achieve the objectives of hypothesis testing, it was necessary to use statistical tests using relevant software tool, it was SPSS version 24 for Windows to find out the positive effect on the variables in this study, lifestyle on the purchasing decision for Samsung smartphone in Jakarta.

\section{B. Measurement of Variables}

In this study, variables were measured using the instrument in the form of a manual questionnaire with the criteria of the owner of the Samsung Galaxy Note or having used the Samsung Galaxy Note. The distribution of consumer questionnaires was carried out through random interactions from several places in Jakarta. Then the assessment for this questionnaire used a Likert scale. According to Sugiyono (2012: 86), Likert scale is a tool used to measure attitudes, opinions, and perceptions of a person or group of people about social phenomena. [12] Every statement on the online questionnaire was assessed with five statements combined with the Likert scale score: 
- Strongly agree with the value of 5

- Agree with the value of 4

- Quite agree with the value of 3

- Disagree with the value of 2

- Strongly disagree with the value of 1

\section{Population and Samples}

The population used in this study was consumers who use Samsung smartphone products in Jakarta. Whereas for the sampling used nonprobability sampling technique by not providing equal opportunities for each element or member of the population to be selected as a sample [8].

Whereas, the type of nonprobability sampling used was judgment sampling which were the samples taken in accordance with the characteristics of the desired population, whoever the respondents, where and when they were encountered, to be used as elements of the research sample [12].

The sampling criteria in this study were determined by the researcher with the relevance to the research object as follows:

- Users of Samsung Galaxy Note smartphone

- Minimal have ever used Samsung Galaxy Note smartphone

Because the number of Samsung Galaxy Note smartphone users in Jakarta was unknown, the formula needed to find out the number of samples was the Lemeshow formula:

$n=\frac{\mathrm{Z}_{1-\alpha / 2}^{2} \times P(1-P)}{d^{2}}$

Notes:

$\mathrm{n}=$ Minimum number of samples required

$\mathrm{Z}=$ The standard value of the distribution matches the value

of $\alpha$ or the level of confidence of 1.96

$\mathrm{P}=$ Estimated recommended proportion of 0.5

$\mathrm{d}=$ The level of precision to be used, $5 \%$ or 0.05

Based on the formula:

Thus, the number of samples used for this study were 384 consumers who use the Samsung Galaxy Note smartphone in Jakarta [17].

\section{Data Analysis}

There were some data analysis techniques in the study, validity and reliability tests, classic assumption tests which were divided into normality tests, multicollinearity tests and heteroscedasticity tests and the last was t test or partial statistical test to test lifestyle variable on purchasing decision.

\section{a. Validity Test and Reliability Test}

A questionnaire instrument is considered feasible to use if it passes the validity and reliability test.

1. Validity Test is used to measure the validity of a questionnaire (Ghozali, 2011: 56). A questionnaire is said to be valid if the question in the questionnaire is able to express something that will be measured by the questionnaire. Validity test is done by conducting a correlation test. Terms of acceptance are if the coefficient of correlation $(r)<r$ table then the item is invalid, otherwise, if the coefficient of correlation $(r)>r$ table then the item is valid.

2. Reliability Test is a test tool to measure the questionnaire in the forms of indicators of variables. A questionnaire is said to be reliable if the respondent's answer to the statement is consistent. The measurement is only done once and the results are compared with other questions or the correlation between the answers of the questions is measured. The SPSS application software provides these facilities by means of Cronbach Alpha statistical test $(\alpha)$ [17].

\section{b. Classic assumption test}

This test was carried out on the regression model used, this was done in order to find out whether the regression model used was good or not [17].

In this study, the classic assumption test used were normality test, multicollinearity test, and heteroscedasticity test, as follows:

1. Normality Test, according to Ghozali (2013: 160), is used to test whether in the regression model, the residual variables have a normal distribution. This study used a normality test using the Kolmogorov-Smirnov technique. In the Kolmogorov-Smirnov test, data are said to be normal if the asymptotic significance is more than 0.05 [17].

2. Multicollinearity Test. Symptoms of multicollinearity occur if there is a strong correlation between the independent variables. The method that can be used to detect the symptoms of multicollinearity is to observe the tolerance value or VIF (variance inflation factor). If the tolerance value is $<0.10$ or VIF value is $>10$ then it shows the symptoms of multicollinearity [18].

3. Heteroscedasticity test aims to test whether in the regression model, there is an inequality of variants from residuals of one observation to another. One method used to determine whether there is a symptom of heteroscedasticity is to look at the scatter plot graph. Basic analysis: If there is no clear pattern, and the points spread above and below the number 0 on the $\mathrm{Y}$ axis, heteroscedasticity does not occur [12].

\section{c. Multiple linier Regression}

This test basically showed the extent of the influence of independent variables individually on the dependent variable. [20] Multiple linier regression analysis is a multivariate application used to test the effect of several independent variables $(\mathrm{X})$ on one dependent variable $(\mathrm{Y})$ which is explained as follows:

$\mathrm{Y}=\alpha+\beta 1 \mathrm{X} 1+\beta 2 \mathrm{X} 2+\beta \mathrm{nXn}+\mathrm{e}$

Notes:

$\mathrm{Y}=$ Dependent variable

$\alpha=$ Constant

$\beta \mathrm{n}=$ Regression coefficient to be tested

$\mathrm{Xn}=$ Indepedent variables

$\mathrm{e}=$ Error 


\section{d. $\quad$ t test}

This test basically showed the extent of the effect of independent variables individually on the dependent variable. However, if the probability value or significance of $t>0.05$, it can be said that there is no significant effect of each variable on the dependent variable [18].

Basic information in the hypothesis, $(\mathrm{H} 0)=$ The null hypothesis represents the condition of the status quo or the current condition believed to be true based on theory or concept. $(\mathrm{Ha})=$ The alternative hypothesis represents the researchers' expectations of the possibility of not applying the status quo or the current condition as part of the objective of the research to be achieved. Based on the information explained, the criteria for testing this hypothesis are:

- $\quad(\mathrm{H} 0): \mathrm{bi}=0$, means that the independent variable has no significant effect on the dependent variable

- $\quad(\mathrm{Ha}):$ bi $\neq 0$, means that the independent variable has a significant effect on the dependent variable. The way to do t test with a significance level $(\alpha)=$ 0.05 is to compare the value of $t$ count with $t$ table.

\section{e. Correlation between dimensions}

This test basically used to show which relationship is the strongest in the dimensions of lifestyle to purchase decision through a correlation matrix between dimensions. Correlation between dimensions were tested using SPSS by means of Pearson Correlation of each independent variable from the results of the research questionnaire partially on purchasing decisions.

\section{RESEARCH RESULTS AND DISCUSSION}

\section{A. Characteristics of Respondents}

This study used 384 respondents as the samples who have characteristics as buyers or consumers of Samsung Galaxy Note smartphone products. The characteristics of the respondents were explained by demographics, included sex, age, education, employment and income. The first demographic was sex with the results of 296 male respondents and 88 female respondents. Then the number of respondents was dominated by 20 to 30 years old with a total of 250 people or with a percentage of $65.2 \%$. The education level of respondents was dominated by $\mathrm{S} 1$ education with 196 people. The characteristic of the respondent's work was dominated by private employees, amounting to 175 people and the highest income-based characteristic was 4 million to 8 million rupiah with 147 people. It can be concluded that the mean respondents were men in the age range of 20 to 30 years old, with the majority of respondents were $\mathrm{S} 1$ graduates and private employees. Most users earned 4 million to 8 million rupiah per month.

\section{B. Validity and Reliability Tests Results of the Lifestyle}

Instrument testing needs to be done before analyzing the hypotheses in this study. Starting with validity test using the Pearson Product Moment method, this method briefly correlates each item score with a total score. Each question that has a significant correlation with the total score indicates the question corresponds to what it wants to express. [5] This study will examine the validity of the lifestyle as the independent variable and purchase decision as independent variable using SPSS version 24 from IBM for the windows operating system. The basis for testing decisions is:

- If $\mathrm{r}$ arithmetic $<\mathrm{r}$ table (tolerance level of 5\% or 0.05) then the question instrument does not correlate significantly with the total score and is declared invalid.

- If $\mathrm{r}$ arithmetic $>\mathrm{r}$ table (tolerance level of $5 \%$ or 0.05 ) then the question instrument has a significant correlation with the total score and is declared valid

- Determine the value of $r$ table using the formula $\mathrm{df}$ $=$ number of cases (n) - 2, with a significance level of $5 \%$. Through the table in the Appendix, the table $r$ value is known as 0.09996

- Determine the value of $r$ arithmetic can be done using the SPSS version 24 for Windows program then the $r$ results for each item (variable) can be seen in the Pearson Correlation column

Then, this study uses the Cronbach Alpha method to test the reliability of each question item [19] so that it can be categorized as follows:

- $\quad 0.80<\mathrm{r} 111.00$ very high reliability

- $0.60<\mathrm{r} 110.80$ high reliability

- $0.40<$ r11 0.60 moderate reliability

- $0.20<$ r11 0.40 low reliability.

- $\quad-1.00$ R11 0.20 very low reliability (not reliable)

The results of the validity test of lifestyle variable showed that the $r$ table value was 0.09996 and the results of $r$ count of each dimension of lifestyle were explained as follows:

- The value of $r$ count activity was $0.689>\mathrm{r}$ table 0.09996 so that it was said to be valid

- The value of $r$ count interest was $0.728>\mathrm{r}$ table 0.09996 so that it was said to be valid

- The value of $r$ count opinion was $0.745>\mathrm{r}$ table 0.09996 so that it was said to be valid

From the lifestyle variable reliability test, it was found the Cronbach's Alpha value of 0.533 which was categorized as moderate reliability

\section{Validity and Reliability Tests Results of the Purchasing Decision}

The results of the validity test of Purchasing Decision variable showed that the $r$ table value was 0.09996 and the results of $r$ count of each dimension of Purchasing Decision were explained as follows

- The value of $\mathrm{r}$ counts the decision about product selection was $0.627>\mathrm{r}$ table 0.09996 so that it was said to be valid

- The value of $r$ counts the decision about brand selection was $0.559>\mathrm{r}$ table 0.09996 so that it was said to be valid 
- The value of $\mathrm{r}$ counts the decision about the time of purchase was $0.545>\mathrm{r}$ table 0.09996 so that it was said to be valid

- The value of $\mathrm{r}$ count payment methods was $0.646>$ $r$ table 0.09996 so that it was said to be valid

- The value of $r$ counts the decision about the selection of outlets/counters was $0.507>\mathrm{r}$ table 0.09996 so that it was said to be valid

From the Purchasing Decision variable reliability test, it was found the Cronbach's Alpha value of 0.503 which was categorized as moderate reliability

\section{Normality Test}

In this study, the Kolmogorov-Smirnov test was used to be able to see the distribution of data with the following conditions:

- If the significance value in the KolmogorovSmirnov column is $>0.05$ then the data can be said to be normally distributed.

- If the significance value is $<0.05$, the data are not normally distributed.

In the study, it was known that the Kolmogorov-Smirnov Significance value was 0.111 , which means $>0.05$. So that it could be assumed that the data were normally distributed.

\section{E. Multicollinearity Test}

A good regression model should not occur correlation between independent variables. If the independent variables are correlated, these variables are not orthogonal. Orthogonal variable is the value of the correlation of independent variables between members of the independent variable must be equal to zero [18]. There are several things that can be done to test multicollinearity, including:

- If the tolerance value is greater than 0.10 then there is no multicollinearity in the regression model

- If the tolerance value is smaller than 0.10 , there will be multicollinearity symptoms in the regression model

- If the VIF value $<$ of 10.00 then it means that there is no multicollinearity in the regression model

- Whereas if the VIF value> 10.00 then multicollinearity occurs in the regression model

Multicollinearity interference did not occur in this study because tolerance value for lifestyle variable was 0.267 , which more than 0.10 . Besides that, the VIF value indicated that the value of the lifestyle variable was 1,574 which less than 10. Thus, there was no Multicollinearity interference between independent variables.

\section{F. Heteroscedasticity Test}

A good regression model is homoskedasticity or heteroscedasticity does not occur. If the variant of the residual observations of another observation remains, then it is called homoscedasticity and if different is called heteroscedasticity. One method used to determine the presence or absence of heteroscedasticity symptoms is to look at a scattler plot graph with the conditions as follows:

- $\quad$ Spread data points above and below the number 0

- Points do not collect above and below only

- Spread of data points may not form wide or narrow wave patterns

- $\quad$ Spread of data points may not form other patterns

Based on the results using a scatter plot graph, the data spread above and below the value of 0 , did not form a widened or narrowed wave and also did not form a particular pattern so that the symptoms of heteroscedasticity did not occur.

\section{G. Results of Multiple Linear Regression Analysis}

Multiple linear regression analysis that aims to determine whether there is influence of independent variables on the dependent variable. Based on the results:

$\mathrm{Y}=\alpha+\beta 1 \mathrm{X} 1+\beta \mathrm{nXn}+\mathrm{e}$

Notes:

$\alpha=10.495$

$\beta 1 \mathrm{X} 1=0.267$

$\beta \mathrm{nXn}=$ other independent variables

$\mathrm{e}=0.87$

Constants / intercept values (a) $=10.495$. This means that the relationship among independent variables to the dependent variable (purchasing decision) is unidirectional or positive and influences the purchasing decision of a Samsung Note smartphone that has the potential to sell 10,495 units. Coefficient X1 (b1) $=0.267$. This means that lifestyle has a positive influence as a unit of $26.7 \%$ on purchasing decisions.

\section{H. $t$ test}

Based on the results of the data processing, the value of $t$ count lifestyle variable was 3.060 and the value of $t$ table was 1.96616 so that $\mathrm{t}$ table $<\mathrm{t}$ count. Then the significance value $(\mathrm{x} 3)$ was $0.002<0.05$ so that the conclusion of the hypothesis for the lifestyle variable $\mathrm{t}$ test was $\mathrm{H} 0$ was rejected and $\mathrm{Ha}$ was accepted. This means that lifestyle has a positive and significant effect on purchasing decision which is in accordance with hypothesis of the study.

\section{Correlation between dimensions}

This test was used to get the highest and lowest correlation between the independent and dependent variables. Lifestyle dimension consists of activities, interests and opinions while the purchase decision dimension consists of the decision about product selection, The decision about brand selection, The decision about the selection of outlets/counters, The decision about the time of purchase and payment methods. The details explanation for each correlation is presented in a table to make it easier to read the data for comparison as follows: 
TABLE I: CORRELATION BETWEEN DIMENSIONS

\begin{tabular}{llll}
\hline \hline Dimension & Activity & Interest & Opinion \\
\hline $\begin{array}{l}\text { The decision about product } \\
\text { selection }\end{array}$ & 0.239 & 0.125 & 0.273 \\
$\begin{array}{l}\text { The decision about brand } \\
\text { selection }\end{array}$ & 0.281 & 0.111 & 0.170 \\
$\begin{array}{l}\text { The decision about the time } \\
\text { of purchase }\end{array}$ & 0.169 & 0.113 & 0.206 \\
$\begin{array}{l}\text { Payment methods } \\
\begin{array}{l}\text { The decision about the } \\
\text { selection of } \\
\text { outlets/counters }\end{array}\end{array}$ & 0.253 & 0.056 & 0.085 \\
\hline \hline
\end{tabular}

Sources: Computed Primary Data, 2019

Based on Table I, shows that the highest correlation value in the lifestyle dimension is activity with a value of 0.281 to purchase decision dimension which is the decision about brand selection and the lowest correlation value in the lifestyle dimension is the opinion with a value of 0.029 to purchase decision dimension which is the the decision about the selection of outlets/counters.

\section{J. Discussion}

Based on the results of the study, partially, lifestyle has a positive and significant effect on purchasing decision. With this result, it can be said that lifestyle is also a determining factor with the support of the most influential activity attributes. Given that every consumer has different activities so the decision in choosing a smartphone brand is adjusted by the needs of each consumer's activity. This is supported by the findings of the study conducted by Putra in [5] which stated that lifestyle affects purchasing decision, besides, products that can introduce the most modern or sophisticated features and technology will make consumers decide to buy these products.

The higher the lifestyle, the higher the purchasing decision, a high lifestyle or luxury will increase the prestige [5]. Lifestyle is related to how people live, how they use their money and how they allocate their time. According to Chaney in [9] there are several forms of lifestyles, lifestyle industry and lifestyle ads, lifestyle industry is an era of prestige, self-appearance increases and becomes essential, body and everyday life become a project, the seed of the style. The current era of information globalization plays a major role in shaping image culture and cultural ideals with the onslaught of advertisements that offer a visual style that affects consumers. Advertisements present a lifestyle by subtly imparting the importance of self-image in public appearance.

\section{CONCLUSION AND RECOMMENDATION}

\section{A. Conclusion}

Based on the test results, it can be concluded that lifestyle has a positive and significant effect on purchasing decision of Samsung Galaxy Note smartphone in Jakarta supported by activity attributes that are the dimensions of lifestyle that most influence to the dimensions of purchasing decision.

This conclusion is supported by the results of testing in multiple linear regression that lifestyle provides an influence of $26.7 \%$ on purchasing decisions. then, based on testing the correlation between dimensions that activity becomes the dominant factor that has the highest correlation value to the dimensions of the purchase decision which is the decision about brand selection.

\section{B. Recommendation}

Based on the results of research, lifestyle becomes a factor with a quite strong effect after product quality on purchasing decision. This can be improved by creating a smartphone product that can affect the lifestyle of particular consumers, for example, the lifestyle of consumers who like shopping for unique products, consumers who have a sophisticated lifestyle and so on.

For other parties who want to continue for future research, the determination of the independent variable can be done by expanding the scope of the existing variable, the lifestyle. This is intended to find out other factors that influence purchasing decision on Samsung smartphone products. Future research is also expected to analyze a broader scope.

\section{ACKNOWLEDGMENT}

Author thank God because of its blessings to give encouragement to work on this article to completion, besides that the authors also thank the lecturer who patiently helps the author work on this article to finish and finally the author want to thank parents and friends who help provide moral assistance and prayer so that this article can be completed.

\section{REFERENCES}

[1] Katadata. (2016). Retrieve from https://databoks.katadata.co.id/datapublish/2016/08/08/penggunasmartphone-di-indonesia-2016-2019

[2] Rosnadi, E. (2014). "Pengaruh Kualitas Produk dan Citra Merek Terhadap Keputusan Pembelian Handphone Merek Samsung Android Pada Mahasiswa Pendidikan Ekonomi Fakultas Ekonomi Universitas Negeri Surabaya.” Jurnal Pendidikan Tata Niaga. Vol. 2, No. 3.

[3] Samsung. (2019). Retrieve from https://www.samsung.com/id/aboutsamsung/company/history/

[4] Statcounter. (2018). http://gs.statcounter.com/vendor-marketshare/mobile/indonesia

[5] Hartono, T., Silintowe, Y. B. R. (2018). "Keputusan Pembelian Smartphone oleh Mahasiswa: Kelompok Acuan atau Gaya Hidup?.” Jurnal Bisnis dan Managemen. Vol. 30 (2): 181-197, ISSN 08521875 / ISSN (Online) 2549-3787.

[6] Fuad, A. (2015). "Pengaruh Gaya Hidup Terhadap Keputusan Pembelian Konsumen Dipurworejo.” Jurnal Manajemen dan Bisnis. Vol. 11, No. 2A.

[7] Purba, A.R.J. (2015). "Pengaruh Gaya Hidup Terhadap Keputusan Pembelian Smartphone Berbasis Android.” Jurnal Prodi Manajemen Bisnis. No. 15.04.764.

[8] Defriansyah, D., Daud, I., Nailis, W. (2016). "Pengaruh Citra Merek, Harga Dan Kualitas Produk Terhadap Keputusan Pembelian Smartphone Samsung (Studi Kasus Mahasiswa Universitas Sriwijaya Indralaya)." Jurnal Ilmiah Manajemen Bisnis dan Terapan. Vol. 13, No. 2.

[9] Wicaksono, A., Suharyono, dan Pangestuti, E. (2018). "Pengaruh International Brand Image Dan Lifestyle Terhadap Keputusan Pembelian.” Jurnal Administrasi Bisnis (JAB)|Vol. 57 No. 2.

[10] Ganlari, D., Deka, Kr. P. dan Duta C. (2016). A Study on Consumer Buying Behavior of Mobile Phones. Journal of Management in Practice Vol. 1, No. 1

[11] Wijonarko, A., Ekowati, T., dan Irawati, D. (2016). "Pengaruh Gaya Hidup Terhadap Keputusan Pembelian Handphone Android (Studi pada Mahasiswa Universitas Muhammadiyah Purworejo).” Jurnal Manajemen dan Bisnis. Vol. 12, No. 2A. 
[12] Zulfajri, Makmur, dan Hidayat. (2017). "Analisis Pengaruh Citra Merek dan Kualitas Produk Terhadap Keputusan Pembelian Handphone Samsung Di Pelita Ponsel Pasir pengaraian.” Jurnal Mahasiswa Fakultas Ekonomi. Vol. 4, No. 1.

[13] Ayodele, A. A., dan Ifeanyichukwu, C. (2016). Factors Influencing Smartphone Purchase Behavior Among Young Adults In Nigeria. International Journal of Recent Scientific Research Research Vol. 7, Issue, 9, pp. 13248-13254.

[14] Cahya, E., dan Harti. (2015). "Pengaruh Kualitas Produk dan Harga Terhadap Keputusan Pembelian Smartphone Sony Xperia tipe Z series di counter Insight Plaza Marina Surabaya." Jurnal Manajemen. Vol. 12, No. 2A.

[15] Revita, M. L. D. E., Frimayasa, A., dan Kurniawan, A. (2018). "Pengaruh Kualitas Produk Terhadap Keputusan Pembelian Smartphone Merek Samsung." Jurnal Penelitian Ilmu Manajemen Vol. 1 No. 1.

[16] Lemeshow, S., Hosmer, Jr. D. M., Klar, J., Lwanga S. K. Sample size determination in health studies: a practical manual / S. K. Lwanga and S. Lemeshow, Geneva, Switzerland, 1991, pp. 1-3.

[17] Arsita, E. E. (2016). "Pengaruh Kualitas Produk, Kepercayaan Merek, Dan Word of Mouth Terhadap Keputusan Pembelian Smartphone Samsung Di Surabaya." Jurnal Manajemen. No. 2448.

[18] Septiawan, M. (2017). "Influence Brand Image, Advertisement and Quality of Product Toward Consumer Buying Intention (Study Case OPPO Buying Intention UIN Jakarta)." Jurnal Ekonomi dan Bisnis. No.35464.

[19] Statistikian. (2012). Retrieve from https://www.statistikian.com/2012/10/uji-reliabilitas-instrumen.html

[20] Investopedia. (2019). Retrieve from https://www.investopedia.com/terms $/ \mathrm{m} / \mathrm{mlr}$.asp

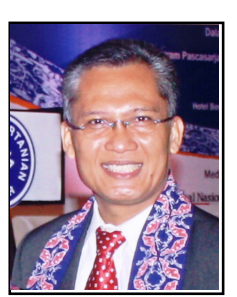

Mohammad Mukti Ali was born in Surabaya, Indonesia. Doctor in Management and Business from the Bogor Agricultural Institute (IPB), besides having served as Expert Staff of the PD Directors. Pasar Surya is one of the BUMDs in Surabaya and the marketing director of the University of Mercu Buana Jakarta, until now served as President Director and owner of PT. Global Teknik Engineering and Marketing \& Management Academy (MMA Center) as well as permanent lecturers in the Postgraduate Program at Mercu Buana University Jakarta and several other universities. Holders of various fields of Competency Certificate from the American Academy of Project Management (AAPM) and the American Academy of Financial Management (AAFM) and BNSP actively participate in various education, training and seminars at national and international also actively become instructors and speakers in various training and seminars in the fields of Management, Marketing, Soft Skill, Technical, Industrial Engineering \& Management System and Operation \& Supply Chain Management both at national and international.

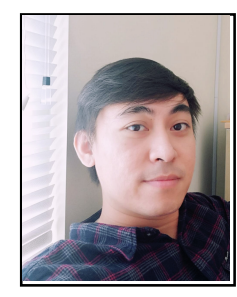

Ryan Tantri Andi was born in Riau, Indonesia. He completed his Bachelor of Science from Bina Nusantara University in 2014. He is currently a Master of Management student at Mercubuana University. 